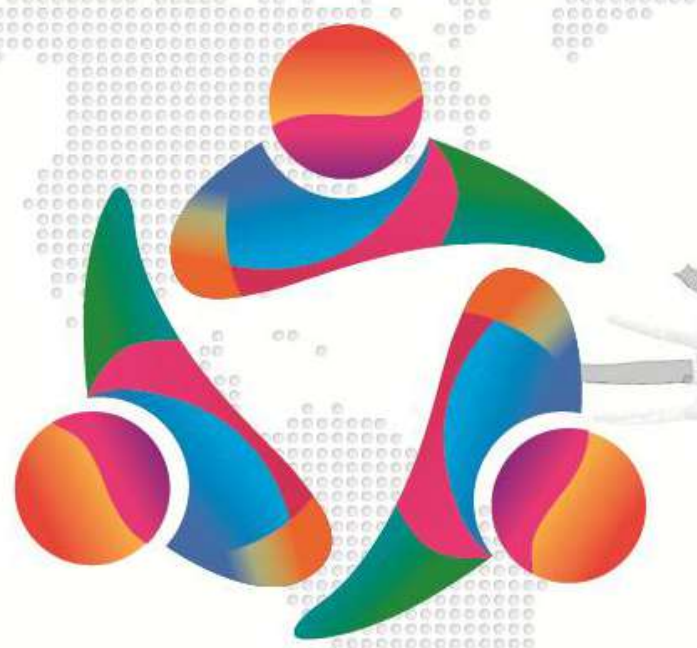

PROCEEDING

ICSS

INTERNATIONAL CONFERENCE OF

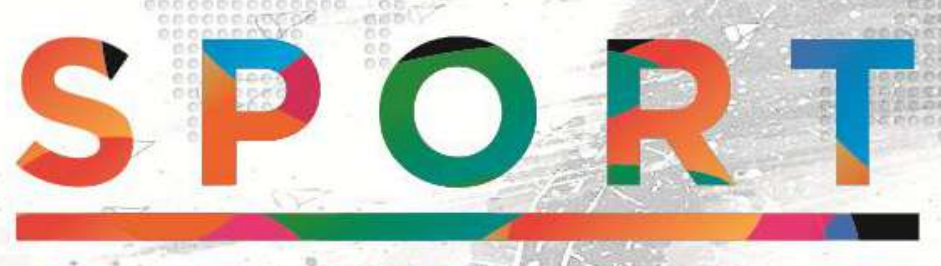

SCIENCE

2016 


\section{INTERNATIONAL CONFERENCE SPORT SCIENCE}

\section{Team Editor:}

Penanggung Jawab

Dr. Edy Mintarto, M.Kes

Dr Nining Widya. K., M. Appl. Sc.

Choirul Umam, S.Pd.

\section{Editor}

Dr. Amrozi Khamidi

Muhammad Fattahilah, S.Pd.

Rosidha A

ISBN 978-602-74679-0-3

Cover Design : Oky Sakti
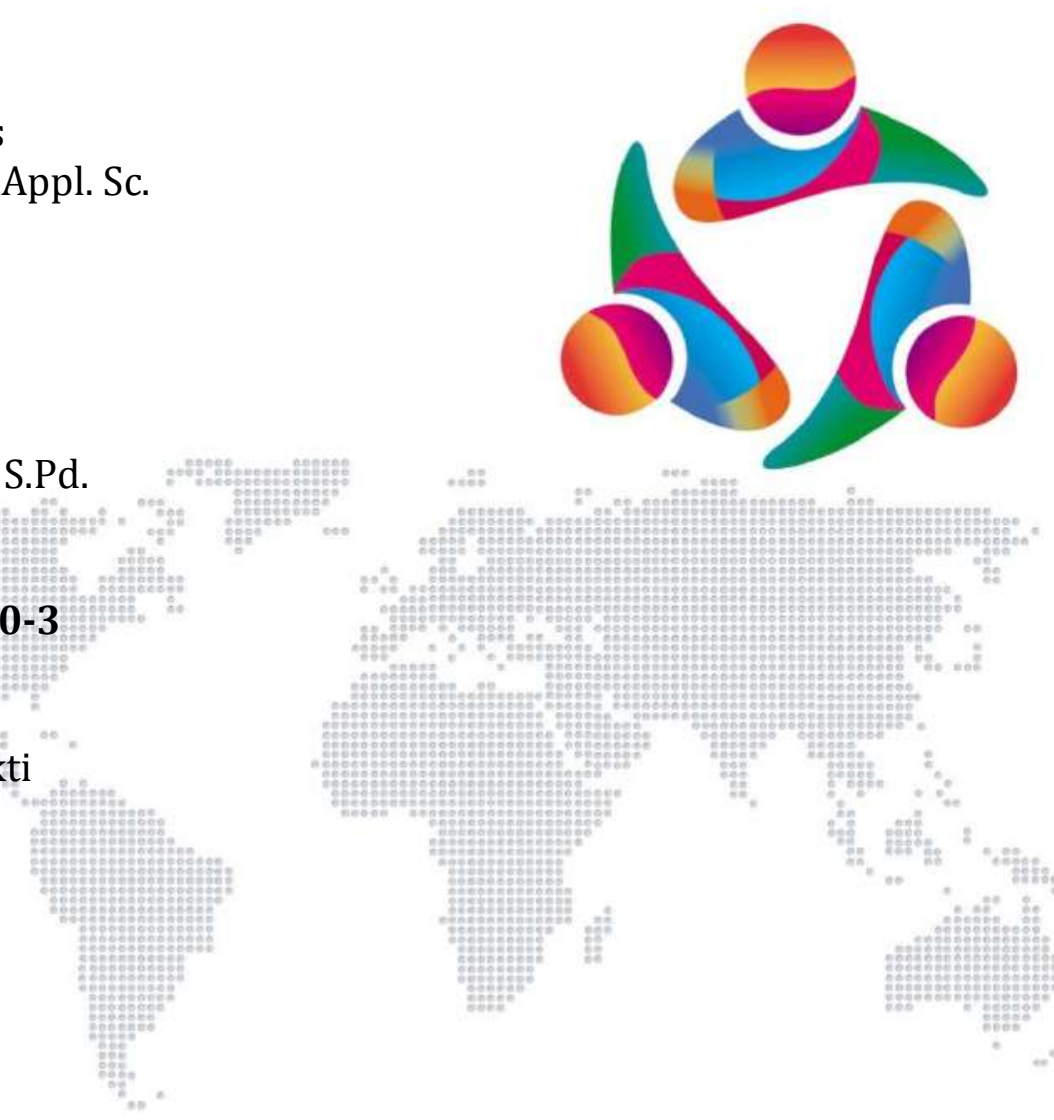

Sport Education Master Program of Universitas Negeri Surabaya Alamat ; Jl. Kampus Unesa Ketintang, Kec. Jambangan, Surabaya @Hak cipta di lindungi oleh Undang-undang 


\section{Preface}

Praise be to Allah the merciful and grateful, we have finished the Proceeding book of International Conference of Sport Science. This book was a draft of an international seminar which is the final project of seminar subjects.

This activity is expected to be a learning tool in particular, as well as a platform to introduce the state university of Surabaya to the academic community. Thus, the future State University of Surabaya can be more open, and more advanced in the application of information and technology as well as the latest sport science.

We are thanks to all of keynote speaker Dr. Greg Eilson ( Australian Strength and Conditioning Association), Gunter Lange (Germany), Dr. Nining Widya K., M.Appl.Sc. (Universitas Negeri Surabaya, Indonesia), Serkan Berber (Anadoulu University, Turkey), Dr. Soumendra Saha (University of Sains Malaysia) and Dr. Yusuf Fuad, M.Sc. (Universitas Negeri Surabaya, Indonesia).

We are thanks to the lecturer as well chief of department of Postgraduate Sports Education of Pascasarjana Unesa, Dr. Edy Mintarto,M.Kes. for support and guidance during we started the process of this conference.

Thanks also to all friends who have worked hard to succeed whole process of international conference. Hopefully in the future, everything we do today can be useful and be equipped very useful in sport studies and other activities of postgraduate of Sport Education of Unesa.

Surabaya, June 1st, 2016

Greetings

Editor,

Fattahilah 
Keynote Speaker

Table of Content

\begin{tabular}{|c|c|c|c|}
\hline No & Name & Materi & Page \\
\hline 1 & $\begin{array}{l}\text { Dr. Greg Wilson } \\
\text { (Australian Strength } \\
\text { and Conditioning } \\
\text { Association) }\end{array}$ & The Future of Strength and Conditioning & 12 \\
\hline 2 & $\begin{array}{l}\text { Gunter Lange } \\
\text { (Germany) }\end{array}$ & Sport Technology and Training & 35 \\
\hline 3 & $\begin{array}{l}\text { Dr. NiningWidya K., } \\
\text { M.Appl.Sc. } \\
\text { (UniversitasNegeri } \\
\text { Surabaya) }\end{array}$ & Model of Talent Identification in Indonesia & 67 \\
\hline 4 & $\begin{array}{l}\text { Serkan Berber } \\
\text { (Anadoulu University, } \\
\text { Turkey) }\end{array}$ & $\begin{array}{l}\text { International Visitors to the } 2014 \text { Sochi Winter } \\
\text { Paralympic Games }\end{array}$ & 85 \\
\hline 5 & $\begin{array}{l}\text { Dr. SoumendraSaha } \\
\text { (USM, Malaysia) }\end{array}$ & $\begin{array}{l}\text { Transforming Higher Education for a Sustainable } \\
\text { Tomorrow }\end{array}$ & 93 \\
\hline 6 & $\begin{array}{l}\text { Dr. Yusuf Fuad, M.Sc. } \\
\text { (UniversitasNegeri } \\
\text { Surabaya Indonesia) }\end{array}$ & $\begin{array}{l}\text { Sports Biomechanics: } \\
\text { Is Only Simple Collection Data? }\end{array}$ & 127 \\
\hline
\end{tabular}

Table of Content

Keynote Speaker

\begin{tabular}{|c|l|l|c|}
\hline No & \multicolumn{1}{|c|}{ Name } & \multicolumn{1}{|c|}{ Materi } & Page \\
\hline 1 & $\begin{array}{l}\text { Serkan Berber } \\
\text { (Anadoulu } \\
\text { University, Turkey) }\end{array}$ & $\begin{array}{l}\text { A Tale of Two Cities: Legacies of the 2012 UEFA } \\
\text { EURO Cup in Gdansk and Lviv }\end{array}$ & 146 \\
\hline 2 & $\begin{array}{l}\text { Stephen P Bird } \\
\text { (Australia) }\end{array}$ & $\begin{array}{l}\text { Preparing The Indonesian Olympic Team: Applications } \\
\text { Of Sport Science In Fatigue Monitoring And Recovery } \\
\text { Management }\end{array}$ & 150 \\
\hline
\end{tabular}




\section{Table of Content}

Sport Education

\begin{tabular}{|c|c|c|c|}
\hline No & Name & Article & Page \\
\hline 1 & $\begin{array}{l}\text { Bustanol Arifin, Frendy } \\
\text { Aru Fantiro (Indonesia ) }\end{array}$ & $\begin{array}{l}\text { A Study On Sport Development Of Relay Snake } \\
\text { And Ladder Game For Elementary School } \\
\text { Students }\end{array}$ & 156 \\
\hline 2 & $\begin{array}{l}\text { Dodik Andi Wicaksono } \\
\text { Setyawan, Marki Sandi, } \\
\text { Satrio Pujo Sasmito, } \\
\text { Ary Prabowo } \\
\text { (Indonesia) }\end{array}$ & $\begin{array}{l}\text { Portrait Of Physical Education And Sports In } \\
\text { Indonesia }\end{array}$ & 160 \\
\hline 3 & $\begin{array}{l}\text { Dwi Catur Andy } \\
\text { Saputro (Indonesia) }\end{array}$ & $\begin{array}{l}\text { Development Games Model Physical Education } \\
\text { Sport And Health Class Iv Elementary School: } \\
\text { Based Teaching Games For Understanding For } \\
\text { Learning Curriculum } 2013\end{array}$ & 164 \\
\hline 4 & $\begin{array}{l}\text { Jusuf Blegur } \\
\text { (Indonesia) }\end{array}$ & $\begin{array}{l}\text { Feedback And Sport Performance: Study At Ppld } \\
\text { Athletes Of East Nusa Tenggara Province }\end{array}$ & 167 \\
\hline 5 & $\begin{array}{l}\text { Puguh Satya } \\
\text { (Indonesia) }\end{array}$ & $\begin{array}{l}\text { Modification Of Learning Model Triple Jump } \\
\text { Subject In Physical Education, Sports, And } \\
\text { Health In Class Xi Sman } 1 \text { Pacet Mojokerto }\end{array}$ & 171 \\
\hline 6 & $\begin{array}{l}\text { Rendra Wahyu } \\
\text { Pradana, Wahyu Indra } \\
\text { Bayu (Indonesia) }\end{array}$ & $\begin{array}{l}\text { The Performance Of Physical Education And } \\
\text { Sports Teacher After The Application Of } \\
\text { Curriculum } 2013 \text { For The Teacher Junior High } \\
\text { Schools In District Jombang }\end{array}$ & 175 \\
\hline 7 & $\begin{array}{l}\text { Ruruh Andayani Bekti } \\
\text { (Indonesia) }\end{array}$ & $\begin{array}{l}\text { The Effect Of Locomotor Learning Toward Motor } \\
\text { Skill Of Students Grade I With Mentally Disabled } \\
\text { (C1) Slb Putera Asih Kota Kediri }\end{array}$ & 180 \\
\hline 8 & Sapto Adi (Indonesia) & $\begin{array}{l}\text { The Effect Of Learning-Time Modification Toward } \\
\text { The Increase Of Physical Fitness, Self-Concept, } \\
\text { And Academic Achievement }\end{array}$ & 183 \\
\hline 9 & $\begin{array}{l}\text { Silvia Mega Novita, } \\
\text { Zakaria Wahyu Hidayat } \\
\text { (Indonesia) }\end{array}$ & $\begin{array}{l}\text { Improved Time Management Skills And Physical } \\
\text { Education Teacher Learning Arenas And Sport } \\
\text { (Studies On Teachers Civil Servants Public } \\
\text { Taman District Sidoarjo Regency) } 2014\end{array}$ & 202 \\
\hline 10 & $\begin{array}{l}\text { Sucahyo Mas'An Al- } \\
\text { Wahid (Indonesia) }\end{array}$ & $\begin{array}{l}\text { Increased Giving Feedback Skills Teachers Of } \\
\text { Physical Education And Health (Studies In } \\
\text { Physical Education Teachers Sports And Health } \\
\text { Pns State Elementary School District At Taman } \\
\text { Sidoarjo Regency) }\end{array}$ & 206 \\
\hline 11 & Wujiati (Indonesia) & $\begin{array}{l}\text { Physical Activity For Early Childhood (Ages } 5 \\
\text { And6 Years) On Early Childhood Education Units } \\
\text { In Indonesia }\end{array}$ & 212 \\
\hline
\end{tabular}


Sport Science and Coaching

Table of Content

\begin{tabular}{|c|c|c|c|}
\hline No & Name & Article & Page \\
\hline 1 & $\begin{array}{l}\text { Abdul Alim, Hari Setijono, } \\
\text { Edy Mintarto (Indonesia) }\end{array}$ & $\begin{array}{l}\text { The Development Of Strength Training Model } \\
\text { To Improve Tennis Serve Techniques Ability For } \\
\text { 15-19 Years Male Athlete Which Were Valid, } \\
\text { Practically, And Effectively }\end{array}$ & 216 \\
\hline 2 & $\begin{array}{l}\text { Adi Sucipto, M.Kes, Dr., } \\
\text { Prof. Toho Cholik Mutohir, } \\
\text { Ma. Ph.D (Indonesia) }\end{array}$ & $\begin{array}{l}\text { The Development Of Instrument For Evaluating } \\
\text { Coaching Competency (lecc) Of Football } \\
\text { Schools }\end{array}$ & 220 \\
\hline 3 & $\begin{array}{l}\text { Agus Hariyanto } \\
\text { (Indonesia) }\end{array}$ & $\begin{array}{l}\text { Efforts To Improve The Quality Of Agility } \\
\text { Through Rope Jump Exercise (Plyometric) With } \\
\text { Interval Training Method } 1: 2 \text { And Interval } \\
\text { Training Method } 1: 3\end{array}$ & 226 \\
\hline 4 & $\begin{array}{l}\text { Ahmad } \\
\text { Hariyanto(Indonesia) }\end{array}$ & $\begin{array}{l}\text { The Effects Of One Leg Hop Bunny Jumps, } \\
\text { Signle Leg-Hoops Progression, Front Cone } \\
\text { Hoops Towards Power, Agility, And Capacity Of } \\
\text { Maximum Aerobics }\end{array}$ & 230 \\
\hline 5 & $\begin{array}{l}\text { Ahmad Nasrulloh, Hari } \\
\text { Setijono, Edy Mintarto } \\
\text { (Indonesia) }\end{array}$ & $\begin{array}{l}\text { The Effects Of The Training Method Of Super } \\
\text { Set And Compound Set With Resting Intervals } \\
\text { Of } 30 \text { And } 120 \text { Seconds Between The Sets } \\
\text { Towards Health Related Fitness }\end{array}$ & 233 \\
\hline 6 & $\begin{array}{l}\text { Albertus Fenanlampir, } \\
\text { M.Pd, Dr. } \\
\text { (Indonesia) }\end{array}$ & $\begin{array}{l}\text { Leadership And Conflict The Organization Sport } \\
\text { Viewed From Cultural Perspective Maluku }\end{array}$ & 237 \\
\hline 7 & $\begin{array}{l}\text { Ali Satia Graha, M.Kes. } \\
\text { Aifo., Dr. } \\
\text { (Indonesia) }\end{array}$ & $\begin{array}{l}\text { Effect Of Combination Therapy With Therapeutic } \\
\text { Exercise Massage Frirage Interruption Of Rom } \\
\text { And Pain On Injury Soccer Athletes Ankle }\end{array}$ & 249 \\
\hline 8 & $\begin{array}{l}\text { Anak Agung Ngurah } \\
\text { Budiadnyana, S.Pd. } \\
\text { (Indonesia) }\end{array}$ & $\begin{array}{l}\text { The Effect Of Bench Press And Chest Press } \\
\text { Through The Strength And Power Of Arm } \\
\text { Muscle In Shorinjikempo'S Athlete }\end{array}$ & 252 \\
\hline 9 & $\begin{array}{l}\text { Angga Indra Kusuma } \\
\text { (Indonesia) }\end{array}$ & $\begin{array}{l}\text { The Effect Of Single Turn Of Rope And Double } \\
\text { Turn Of Rope Exercise Against Increased Arm } \\
\text { Muscle Power And Leg Muscle Power }\end{array}$ & 255 \\
\hline
\end{tabular}




\begin{tabular}{|c|c|c|c|}
\hline 10 & $\begin{array}{l}\text { Ardiansyah D. Kandupi } \\
\text { (Indonesia) }\end{array}$ & $\begin{array}{l}\text { The Effect Of Double-Leg Zig Zag Hop And } \\
\text { Barrier Hop With Depth Jump And Rimp Jump } \\
\text { To The Stregth And Power Of Leg Muscless }\end{array}$ & 258 \\
\hline 11 & $\begin{array}{l}\text { Aridhotul Haqiyah } \\
\text { (Indonesia) }\end{array}$ & $\begin{array}{l}\text { The Effect Of Intelligence, Eye-Hand-Leg } \\
\text { Coordination And Balance On The Pencak Silat } \\
\text { Punch And Kick Coordination }\end{array}$ & 264 \\
\hline 12 & $\begin{array}{l}\text { Arnaz Anggoro Saputro } \\
\text { (Indonesia) }\end{array}$ & $\begin{array}{l}\text { The Comparison Of Learning Make A Match } \\
\text { Method And Think Pair Share Model Toward } \\
\text { The Study Result Of Basketball Dribble }\end{array}$ & 267 \\
\hline 13 & $\begin{array}{l}\text { Bambang Priyonoadi } \\
\text { (Indonesia) }\end{array}$ & $\begin{array}{l}\text { Effectiveness Of Different Sports Massage, } \\
\text { Massage Circulo And Massage Frirage } \\
\text { Modulation Levels Of Immunoglobulin Enzyme A } \\
\text { (Iga) }\end{array}$ & 273 \\
\hline 14 & $\begin{array}{l}\text { Deddy Whinata } \\
\text { Kardiyanto, S.Or., M.Pd } \\
\text { (Indonesia) }\end{array}$ & $\begin{array}{l}\text { Potential And International Level Performance } \\
\text { Achievements Actualization Coach And Athlete } \\
\text { Sports Paralympic Indonesia And Development } \\
\text { Model System Coaching }\end{array}$ & 276 \\
\hline 15 & $\begin{array}{l}\text { Desak Wiwin Try } \\
\text { Swandewi (Indonesia) }\end{array}$ & $\begin{array}{l}\text { The Influence Of Massed Practice And } \\
\text { Distributed Practice Method Toward The } \\
\text { Increasing Of Forehand And Backhand Skills To } \\
\text { The Male Students Of Satya Bhuwana Tennis } \\
\text { School Gianyar Year } 2014\end{array}$ & 280 \\
\hline 16 & $\begin{array}{l}\text { Endang Rini Sukamti, } \\
\text { M.S., Dra. } \\
\text { (Indonesia) }\end{array}$ & $\begin{array}{l}\text { The Development Of The Model For Artistic } \\
\text { Gymnastics Talent Scouting On Early Childhood }\end{array}$ & 284 \\
\hline 17 & $\begin{array}{l}\text { Fahrur Rozi, Yanus } \\
\text { Setyowati (Indonesia) }\end{array}$ & $\begin{array}{l}\text { Indicator Swimming Skills Test And } \\
\text { Anthropometric Measurements Were Used To } \\
\text { Identify Athletes Seeds Talented Swimming } \\
\text { Sports }\end{array}$ & 289 \\
\hline 18 & $\begin{array}{l}\text { Faisol Choirul Sani, Andri } \\
\text { Aritianto (Indonesia) }\end{array}$ & $\begin{array}{l}\text { Ability Comparison Motor Skills Elementary } \\
\text { School Student In Plateau And Lowland In Sub- } \\
\text { Province Magetan }\end{array}$ & 292 \\
\hline 19 & $\begin{array}{l}\text { Faizal Januariansyah } \\
\text { (Indonesia) }\end{array}$ & $\begin{array}{l}\text { Implementation Of Junior Basketball League } \\
2014 \text { Surabaya }\end{array}$ & 295 \\
\hline
\end{tabular}




\begin{tabular}{|c|c|c|c|}
\hline 20 & Firmansyah (Indonesia) & $\begin{array}{l}\text { Effect Of Exercise Crocodilepush Up And T } \\
\text { Push Up To The Arm Muscle Strength And } \\
\text { Muscle Power Arm }\end{array}$ & 303 \\
\hline 21 & $\begin{array}{l}\text { Hendro Budi Surahman, } \\
\text { S.Or. (Indonesia) }\end{array}$ & $\begin{array}{l}\text { The Effect Of Strength Training Arm Overhead } \\
\text { Clear Drill To Power Of Arm And Precision } \\
\text { Punch Of Forehand Clear And Exercise Drive In } \\
\text { Badminton }\end{array}$ & 307 \\
\hline 22 & $\begin{array}{l}\text { Himawan Wismanadi, } \\
\text { M.Pd., Dr. } \\
\text { (Indonesia) }\end{array}$ & $\begin{array}{l}\text { Plyometric exercises influence over Berrier } \\
\text { hexagon and the Explosive Muscle Power Limbs } \\
\text { (power) in the Women's Team Basketball } \\
\text { Surabaya }\end{array}$ & 310 \\
\hline 23 & $\begin{array}{l}\text { I Gede Dharma } \\
\text { Utamayasa,S.Pd. } \\
\text { (Indonesia) }\end{array}$ & $\begin{array}{l}\text { The Effect Of Hurdle Hops Training On Interval } \\
1: 6 \text { And 1:8 Toward The Improvement Of The } \\
\text { Power And Strength }\end{array}$ & 314 \\
\hline 24 & $\begin{array}{l}\text { I Ketut Iwan Swadesi } \\
\text { (Indonesia) }\end{array}$ & $\begin{array}{l}\text { The Effects Of Interval Ratio - Scaled Circuit } \\
\text { Intensity Training Towards The Increase Of } \\
\text { Power, Agility, Speed, And Vo2 Max (Maximum } \\
\text { Volume Of Oxygen }\end{array}$ & 319 \\
\hline 25 & $\begin{array}{l}\text { I Komang Muna Palguna, } \\
\text { S.Pd. (Indonesia) }\end{array}$ & $\begin{array}{l}\text { The Effect Of Star Drill, Single-Leg Hops And E- } \\
\text { Movement, Zigzag Drill Exercises Towards } \\
\text { Agility And Leg Muscle Power }\end{array}$ & 322 \\
\hline 26 & $\begin{array}{l}\text { I Made Rajat Sanjaya, S.Pd } \\
\text { (Indonesia) }\end{array}$ & $\begin{array}{l}\text { The Influence Of Acceleration Sprints And In- } \\
\text { Out Sprint To Speed And Agility }\end{array}$ & 325 \\
\hline 27 & $\begin{array}{l}\text { Kunjung Ashadi } \\
\text { (Indonesia) }\end{array}$ & $\begin{array}{l}\text { The Implementation Of Hidration Program In } \\
\text { Badminton Athletes Of East Java Pplp }\end{array}$ & 328 \\
\hline 28 & $\begin{array}{l}\text { Lalu Moh Yudha Isnaini } \\
\text { (Indonesia) }\end{array}$ & $\begin{array}{l}\text { Effect Of High Intensity And Low Intensity } \\
\text { Plyometric Training Toward Leg Muscle } \\
\text { Strength And Explosive Power }\end{array}$ & 333 \\
\hline 29 & $\begin{array}{l}\text { Mahmud Yunus } \\
\text { (Indonesia) }\end{array}$ & $\begin{array}{l}\text { The Effective Gear Ratio And The High Climbs } \\
\text { To A Maximum Speed For Novice Cyclists }\end{array}$ & 340 \\
\hline 30 & $\begin{array}{l}\text { Marzuki, M.Si., Dr. } \\
\text { (Indonesia) }\end{array}$ & $\begin{array}{l}\text { The Effect Of Exercise Drill Ladder Single, } \\
\text { Double Punch Drill Ladder, Ladder Speed Run, } \\
\text { Run Ladder Stride, Chest Press, Press } \\
\text { Shoulder, Leg Press, Leg Extension Of The } \\
\text { Explosive Power Muscle, Strength, And Speed }\end{array}$ & 344 \\
\hline 31 & Muh Usba (Indonesia) & $\begin{array}{l}\text { The Effect Of Wave Squat And Double Leg Hop } \\
\text { Progression With A Leg Press And Calf Sitting }\end{array}$ & 347 \\
\hline
\end{tabular}




\begin{tabular}{|c|c|c|c|}
\hline & & On Leg Muscle Strength And Power & \\
\hline 32 & $\begin{array}{l}\text { Muhammad Agusman } \\
\text { (Indonesia) }\end{array}$ & $\begin{array}{l}\text { The Effect Of Z-Pattern Run Drill Exercise And } \\
\text { Barrier Jump With Cut And Sprint Towards Leg } \\
\text { Mucles' Agility And Power }\end{array}$ & 351 \\
\hline 33 & $\begin{array}{l}\text { Muhammad Fattahillah, } \\
\text { S.Pd. , Dr. Edy Mintarto, } \\
\text { M.Kes. (Indonesia) }\end{array}$ & $\begin{array}{l}\text { Contribution Of Arm Strength, Back Strength } \\
\text { And 30M Sprint Towards Javelin }\end{array}$ & 356 \\
\hline 34 & $\begin{array}{l}\text { Muhammad Imam Fuadi } \\
\text { (Indonesia) }\end{array}$ & $\begin{array}{l}\text { The Comparation Between Speech And } \\
\text { Demonstration Methods Toward The Study } \\
\text { Result Of Junior High School In Free Style } \\
\text { Swimming (Crawl) }\end{array}$ & 358 \\
\hline 35 & $\begin{array}{l}\text { NikmatulAini, Bima } \\
\text { (Indonesia) }\end{array}$ & $\begin{array}{l}\text { Identification of Supporting and Obstacle } \\
\text { Factors of Swim Coaching in Petrokimia Gresik } \\
\text { Club }\end{array}$ & 361 \\
\hline 36 & $\begin{array}{l}\text { Nortje Anita Kumaat } \\
\text { (Indonesia) }\end{array}$ & $\begin{array}{l}\text { Influence Of Aerobic Exercise On Aerobic } \\
\text { Capacity And Self Well Being }\end{array}$ & 365 \\
\hline 37 & Oce Wiriawan (Indonesia) & $\begin{array}{l}\text { Comparison Of Physical Fitness Junior High } \\
\text { School Based On Highlands And Lowland }\end{array}$ & 369 \\
\hline 38 & Peby Gunarto (Indonesia) & $\begin{array}{l}\text { The Influence Of Drill And Alley Rally Training } \\
\text { Methods To The Accuracy Of Groundstroke } \\
\text { Forehand Topspin And Groundstroke Backhand } \\
\text { Topspin On Tennis }\end{array}$ & 375 \\
\hline 39 & Puguh Satya (Indonesia) & $\begin{array}{l}\text { Modification Of Learning Model Triple Jump } \\
\text { Subject In Physical Education, Sports, And } \\
\text { Health In Class Xi Sman } 1 \text { Pacet Mojokerto }\end{array}$ & 377 \\
\hline 40 & $\begin{array}{l}\text { Rahayu Prasetiyo } \\
\text { (Indonesia) }\end{array}$ & $\begin{array}{l}\text { Differencees Emotional Intelegence Between } \\
\text { Combat And Non Combat Athlete }\end{array}$ & 381 \\
\hline 41 & Rina Nopiana (Indonesia) & $\begin{array}{l}\text { The Effect Of Massage And Stretching On High } \\
\text { And Low V02Max In Recovery Of Blood Lactit } \\
\text { Acid And Heart Rate After Sport Activities. }\end{array}$ & 385 \\
\hline 42 & $\begin{array}{l}\text { Risfandi Setyawan, Mecca } \\
\text { Puspitaningsari } \\
\text { (Indonesia) }\end{array}$ & $\begin{array}{l}\text { Effect Of High-Intensity Interval Training (Hiit) } \\
\text { Versushigh Volume Endurance Training } \\
\text { Program (Hvet) To The Improvement Of } \\
\text { Vo2Max, Vj And Power For Mens Volleyball } \\
\text { Players }\end{array}$ & 390 \\
\hline 43 & Ritoh Pardomuan & Analysis Of Supporting Factors For Potential & 394 \\
\hline
\end{tabular}




\begin{tabular}{|c|c|c|c|}
\hline & (Indonesia) & Athletes In Basketball & \\
\hline 44 & $\begin{array}{l}\text { Rizky Aris Munandar, M.Pd } \\
\text { (Indonesia) }\end{array}$ & $\begin{array}{l}\text { The Effect Of Training Cable Crossover And } \\
\text { Shoulder Press To Increase The Strength Of } \\
\text { Arm Muscles }\end{array}$ & 398 \\
\hline 45 & Rumi lqbal (Indonesia) & $\begin{array}{l}\text { Training Model Development Of Dribbling - } \\
\text { Shooting And Dribbling - Passing In Football }\end{array}$ & 404 \\
\hline 46 & $\begin{array}{l}\text { Sapto Wibowo, M.Pd, Lucy } \\
\text { Widya Fathir, M.Pd } \\
\text { (Indonesia) }\end{array}$ & $\begin{array}{l}\text { The Provision Of Suplementasi Extract Paullinia } \\
\text { Cupana And Camellia Sinensis In Pre Elderly Of } \\
\text { The Performance Of Physical When Exercising }\end{array}$ & 408 \\
\hline 47 & Serkan Berber (Turkey) & $\begin{array}{l}\text { A Tale Of Two Cities: Legacies Of The } 2012 \\
\text { Uefa Euro Cup In Gdansk And Lviv }\end{array}$ & 411 \\
\hline 48 & Sigit Nugroho (Indonesia) & $\begin{array}{l}\text { Effect Of Circuit Exercise And Trapping Circuit } \\
\text { With Regular And Decreased Rest Interval } \\
\text { Toward The Ability Of Strength, Speed, Agility, } \\
\text { Vo2 Max, Power And Recovery }\end{array}$ & 415 \\
\hline 49 & Siti Maifah (Indonesia) & $\begin{array}{l}\text { Effect Of Exercise Ladder Crossover Drill And } \\
\text { Ladder Speed Run Agility And Speed ( Studi } \\
\text { Students Fkip Jpok Banjarbaru } 2012 \text { University } \\
\text { Lambung Mangkurat ) }\end{array}$ & 420 \\
\hline 50 & $\begin{array}{l}\text { Siti Nurrochmah } \\
\text { (Indonesia) }\end{array}$ & $\begin{array}{l}\text { The Effectiveness Training Load Of Dynamic } \\
\text { Increasing Capabilities Physical Condition }\end{array}$ & 426 \\
\hline 51 & Stephen P. Bird & $\begin{array}{l}\text { Preparing The Indonesian Olympic Team: } \\
\text { Applications Of Sport Science In Fatigue } \\
\text { Monitoring And Recovery Management }\end{array}$ & 431 \\
\hline 52 & $\begin{array}{l}\text { Sulaiman, Radita Dwi } \\
\text { Candra (Indonesia) }\end{array}$ & $\begin{array}{l}\text { Influence Of Training Methods And Motor } \\
\text { Educability To Ability Of Playing Football }\end{array}$ & 436 \\
\hline 53 & Sungkowo (Indonesia) & $\begin{array}{l}\text { Contribution To Goal Setting And Concentration } \\
\text { Swimming Athletes Of Achievement }\end{array}$ & 442 \\
\hline 54 & Suryansyah (Indonesia) & $\begin{array}{l}\text { Effect Of Exercise Hexagon Drill And Lateral } \\
\text { Jump Ovr Barrier Against Increase Agility And } \\
\text { Limb Muscle Power On Students Extracurricular } \\
\text { Taekwondo At Sman } 7 \text { Mataram }\end{array}$ & 445 \\
\hline 55 & $\begin{array}{l}\text { Thoriq Rahmad Wakhid } \\
\text { (Indonesia) }\end{array}$ & $\begin{array}{l}\text { The Effect Of Jump Box Exercise Influence And } \\
\text { Reactive Jump Over Hurdles To Limb Muscle } \\
\text { Strength And Power }\end{array}$ & 450 \\
\hline
\end{tabular}




\begin{tabular}{|l|l|l|c|}
\hline 56 & $\begin{array}{l}\text { Tiasari Janjang Suminar, } \\
\text { Oktanda Prima Utama } \\
\text { (Indonesia) }\end{array}$ & $\begin{array}{l}\text { The Development Of Aerobic Gymnastics With } \\
\text { Zumba Combinatoin Through Learning Videos } \\
\text { For Students Of Class Viii In Smp Negeri 2 } \\
\text { Malang }\end{array}$ & 455 \\
\hline $\begin{array}{l}\text { Wawan Setiawan } \\
\text { (Indonesia) }\end{array}$ & $\begin{array}{l}\text { The Influence Of Balinese Traditional Game To } \\
\text { The Physical Fitness And Basic Motoric Skill Of } \\
\text { The 5Th Graders Male Students In Elementary } \\
\text { School 1 Melaya }\end{array}$ & 458 \\
\hline $\begin{array}{l}\text { Yonny Herdyanto } \\
\text { Indonesia) }\end{array}$ & $\begin{array}{l}\text { "Effect Of Training Ikie Punch, Chimney Jump, } \\
\text { Chest Press Seated On Wellness Ball, And Leg } \\
\text { Extension Standing Against Agility, Balance, } \\
\text { Power Arm And Leg On Student S1 Sport } \\
\text { Coaching Education Department Faculty Of } \\
\text { Sport Science Unesa" }\end{array}$ & 461 \\
\hline 59 & $\begin{array}{l}\text { Zakaria Wahyu Hidayat, } \\
\text { Silvia Mega Novita, Choirul } \\
\text { Umam (Indonesia) }\end{array}$ & $\begin{array}{l}\text { Performance Evaluation Referee - Jury East } \\
\text { Java Regional Championship 2016 }\end{array}$ & 464 \\
\hline
\end{tabular}




\title{
FEEDBACK AND SPORT PERFORMANCE: STUDY AT PPLD ATHLETES OF EAST NUSA TENGGARA PROVINCE
}

\author{
Jusuf Blegur \\ Artha Wacana Christian University, Kupang \\ e-mail: blegur04@yahoo.co.id
}

\begin{abstract}
This study reports the implementation feedback on sport performance of athlete at the PPLD East NusaTenggara (ENT) Province. This study used a qualitative approach with type of phenomenology. The research subjects were two athletes who had have international achievements which determined by using purpose sampling technique. The data was collected by participation observation, interview, and documentation. The result of the study found that the extrinsic feedback is still dominates in improving sport performance of PPLD athletes. Coaches and athletes used verbal and non-verbal feedback which are positive, affirmative, and constructive this enhancing self-esteem, self-confidence, and self-efficacy of the athletes. Moreover, with the feedback make the athlete more eager and diligent in practice to improve their sport performance.
\end{abstract}

Keywords: Feedback, sport, performance, athlete.

\section{INTRODUCTION}

Feedback is a generic term that describes a person receives sensory information about motor skills performance during or after performing a task (Magill, 2001:236; Perez, et al., 2009:30). When giving feedback, the information must bein accordance with authentic data on athletes performance to motivate athletes to practice diligently. Landin convey that give feedback in the form of verbal cues show the important characteristics that facilitate the performance of the task (Tzetzis, et al., 2008:371). Junior, et al. (2012:456) added during practice, feedback that inconsistent and incorrect gradually reduced by negative feedback so that athletes can achieve functional stabilization. Furthermore, Orbach and colleagues found people who receive feedback controlled and unstable about the performance experienced more positive emotions (full of hope and more motivated) than those who received feedback is not controlled and stable (Foll, et al., 2008:77).

The idea Feltz and colleagues that is adopted by Short \& Ross-Stewart (2009:227), explaining although feedback is considered the best, communications strategy based to build more self-confidence associated with the source of verbal persuasion. When the process of training, the trainer can implementate verbal and non-verbal feedback to improve the sport performance of athletes. This can be done simultaneously with the process of training and an end. According to Bandura, feedback given to the athlete can damage self-efficacy, or vice versa (Short \& Ross-Stewart, 2009:248), even for beginners athletes, providing feedback in the form of error correction, praise, or criticism implicated to self-confidence him (Smith, et al. in Tzetzis, et al., 2008:372), forming a self adjustment and the ability of the athlete (Boen, et al., 2008:621). Athletes begin to form an impression about himself basis on the its experience and the nature of the feedback obtained on performance (Tzetzis, et al., 2008:371), Hal and Kerr found the feedback and commitments associated with goal setting and sport performance (Kingston \& Wilson, 2009:114), as well as playing an important role in the study of motion (Markland \&Martinek, 1988: 290; Weng, 2014:130).

The advantage of focusing on the results of the individual movements is not only important with regard to the instructions provided, but the implications for the feedback given to athletes (Wulf, et al., 2002:172). During exercise, the athlete always pay attention to listen to and follow the coaches instructions. The attention is used by coaches to foster self-esteem, self-confidence, and self-efficacy athletes. During the passage of the 
training process, coaches are paying attention and special notes on the skills that have not been up to expectations and aims of the exercise, so that a feedback on the constraints that are still being felt athletes during training or competition. Thereby, when giving feedback, coaches need to consider the right time to keep the emotional stability of the athletes for the sport performance.

\section{METHOD}

This study used a qualitative approach as a method to show feedback phenomenon and sport performance of athletes. The subject is determined by three criteria, including: 1) Athlete athletics in the rarely run; 2) Athletes who are members of the ENT provincial regional training center; and 3) Athletes who have had international achievement. Referring to the three criteria, it was determined Oliva Sadi and AfrianaPaijo as a research subject. In addition to these two subjects, researchers also explore and enrich the information from different sources, for example, coaches together during practice and everyday life. Data collected by participation observation, interview, and documentation. Analysis of data includes, data presentation, data reduction, set up a theme, and conclusion or meaning.

\section{RESULT AND DISCUSSION}

\section{Time Record as Effective Feedback}

Record the time used athletes as effective feedback for sport performance during the competition. For example, senior championships April 2014, number followed by 1,500 meters he a record time 4:45:20, while in 2015 the same number, he was only able to record time of 5:02:33, with the time of automatic performance declined. These results were used as evaluation materials for coaches and athletes to do repairs during exercise process to improve performance further ahead of the competition. When compete, athletes record time to limit the energy used in each track so that the effective and efficient and the wait time is right to explore the largest capacity. Time and steps that have been set up during exercise, such as, at 1,500 meters in the first 300 meters athlete had to be in 53 seconds. Looking at the results of the study, the more dominant athlete using extrinsic feedback to sport performance. It is marked with this feedback comes from a time during or after the act or process so that matching with the idea Fischman\&Oxendine (2001:22) and Weng (2014:131).

\section{Feedback Verbal and Non-Verbal Improve the Spirit Athletes}

The presence of coaches during the competition give a positive impact on the mood of the athlete. Standing next to the field, while looking at the stopwatch, the expression of bodily gestures "edgy" and symbol to the rhythm of athlete's foot is able to improve the expectations of success, and passion of the athlete's performance. Verbal feedback used by coaches in encourage athletes was:"Remember to stay focused and keep the steps you must champion" there are also: "Prove that we (ENT province) can also get achievements". This (verbal feedback) according to the athlete is very affects the psychological, he felt happy, excited, and motivated to win the competition by attempting to outperform other competitors. The results of this study support the study of Foll, et al. (2008:77) that the feedback can increase expectations of success, mental reactions, and persistence of behavior and result Fishbach (2010:528); Minoo, et al. (2014:532) that positive feedback of trainers encourage attribution of mood improve the motivation of athletes.

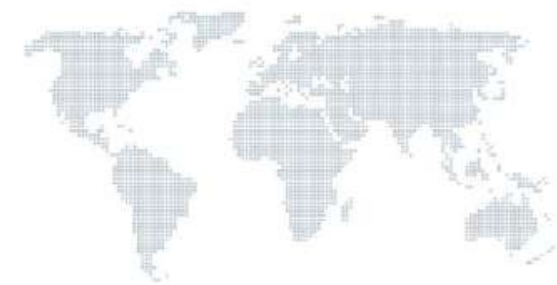




\section{Self Introspection with Feedback from Coach and Colleague}

Outside the arena of competition, coaches and colleagues also always give attention, passion, and motivation to athletes thus enhancing self-esteem, self-confidence, and self-efficacy. This method motivates athletes to improve concentration and improve themselves to sport performance. For example, a colleague who always gives feedback by saying: "My sister arm must be swung total (while providing an example of the movement)". With such feedback, the athletes are always open, happy, and feel cared so he was always correct weaknesses and improve strengths for sport performance. The results of this study support investigation of Kamal and colleagues that feedback is important to prove a self-esteem athletes (Kamal, et al., 1992:955), increasing the selfconfidence of athletes (McCarty, 1986:840), forming the adjustment yourself and the ability of the athlete (Boen, et al., 2008:621). Moreover, it also supports research Karl, et al. (1993:379); Escarti\& Guzman (1999:83); Mahoney, et al. (2008:39) that the feedback can improve self efficacy athletes.

\section{CONCLUSION}

Giving feedback to the athlete should pay attention to the characteristics of the sport, mood, time, and place of the implementation. If these aspects are not addressed, then giving feedback will only damage the self-esteem, self-confidence, and self-efficacy athletes to leads to the poor sport performance. Extrinsic feedback is still dominate the sport performance. Verbal and non-verbal feedback equally give effect to the spirit and passion of sport performance. Athletes' openness to feedback from coaches and colleagues must be used to improve sport performance athletes, but it need be noted that the athletes have been more pleased with the feedback that is positive, affirmative, and constructive.

\section{REFERENCE}

Boen, F., Hoye, K.V., Auweele, Y.V., Feys, J., \& Smits, T. (2008). Open Feedback in Gymnastics Judging Causes Conformity Bias Based on Informational Influencing. Journal of Sport Sciences, 26(6), 621-628.

Escarti A. \& Guzmán J.F. (1999) Effects of Feedback on Self-Efficacy, Performance, and Choice in an Athletic Task. Journal of Applied Sport Psychology, 11, 83-96

Fishbach, A., Eyal, T., \& Finkelstein, S.R. (2010). How Positive and Negative Feedback Motivate Goal Pursuit. Social Personality Psychology Compass, 4(8), 517-530.

Foll, D.L., Rascle, O., \& Higgins, N.C. (2008). Attributional Feedback Changes in Functional and Dysfunctional Attributions, Expectations of Succes, Hopefulness, and Short-Term Persistence in a Novel Sport. Psychology of Sport and Exercise, 9, 77-101.

Junior, C.M.M., Maia, J.A.R., \& Tani, G. (2012). Frequency and Precision of Feedback and the Adaptive Process of Learning a Dual Motor Task. Rev. Bras. Educ. Fis. Esporte, Sao Paulo, 26(3), 455-462.

Kamal, A.F., Blais, C., McCarrey, M., Laramee, D., \& Esktrand, K. (1992). Informational Feedback and Self-Esteem among Male and Female Athletes. Psychological Reports, 70, 955-960.

Karl, K.A., O’Learly-Kelly, A., \& Martocchio, J.J. (1993). The Impact of Feedback and Self-Efficacy on Performance in Training. Journal of Organization Behavior, 14(4), 379-394.

Kingston, K.M. \& Wilson, K.M. (2009). The Application of Goal Setting in Sport. In S.D. Mellalieu \& S. Hanton (Ed.). Advances in Applied Sport Psychology: AReview (pp. 75-123). $1^{\text {st }}$ Edition. Madison Avenue, New York: Routledge. 
Magill, R.A. (2001). MotorLearning: ConcpetsandApplications. $6^{\text {th }}$ Edition. New York: McGraw-Hill Companies, Inc.

Mahoney, A.J., Devonport, T., \& Lane, A.M. (2008). The Effects of Interval Feedback on the Self-Efficacy of Netball Umpires. Journal of Sport Science and Medicine, 7, 3946.

Markland, R. \& Martinek, T.J. (1988). Descriptive Analysis of Coach Augmented Feedback Given to High School Varsity Female Volleyball Players. Journal of Teaching in Physical Education, 7, 289-301.

McCarty, P. A.. (1986). Effects of Feedback on the Self-Confidence of Men and Women. The Academy of Management Journal, 29(4), 840-847.

Minoo, D., Nasser, B., \& Misagh, H. (2014). The Effect Coach's Feedback Behaviors on Intrinsic and Satisfaction in Elite Athletes of Golestan Province. EuropeanJournalofExperimentalBiology, 4(1), 523-526.

Perez, P., Llana, S., Brizuela, G., \& Encarnacion, A. (2009). Effect of Three Feedback Conditions on Aerobic Swim Speeds. Journal of Sport Science and Medicine, 8, 3036.

Short, A. \& Stewart-Roos, L. (2009). A Review of Self-Efficacy Based Interventions. In S.D. Mellalieu \& S. Hanton (Ed.). Advances in Applied Sport Psychology: AReview (pp. 221-280). $1^{\text {st }}$ Edition. Madison Avenue, New York: Routledge.

Tzetzis, G., Votsis, E., \& Kourtessis, T. (2008). The Effect of Different Corrective Feedback Methods on the Outcome and Self Confidence of Young Athletes. JournalofSportScienceMedicine, 7, 371-378.

Weng, C.Y. (2014). The Effect of Different Feedback Methods Impact the Leaning of Novice Badminton Forehand Serve in Fifth Grade Students. US-China Educational Review, 4(2), 130-138.

Wulf, G., Nathan, Mc., Gartner, M., \& Schwarz, A. (2002). Enhancing the Learning of Sport Skills through External-Focus Feedback. Journal of Motor Behavior, 34(2), 171-182. 